\title{
The Effect Of Sugar Concentration on the Organoleptic Quality of Liberika Tungkal Jambi Instant Coffee
}

\author{
Mursalin Mursalin*, Addion Nizori, Irma Rahmayani \\ \# Departmen of Agricultural Technology, Universitas Jambi, Kampus Pondok Meja Jl Tribrata Km 11, Jambi, 36361, Indonesia \\ E-mail:_mursalin@unja.ac.id
}

\begin{abstract}
This study aimed to determine the effect of sugar concentration on the organoleptic quality of instant coffee of Liberika Tungkal Jambi and to determine the optimal concentration of sugar in producing instant coffee with the best organoleptic quality. Instant coffee was produced by co-crystallization method. The crystallizing agent used was granulated sugar. Coffee extract was made using an extractor in a ratio of coffee powder/hot water of $1 / 15$. Five levels of sugar concentration $(15,25,35,45$ and $55 \%)$ were applied in a completely randomized design with 4 replications. The parameters observed were the sweetness level, the distinctive aroma of coffee, the granules texture, and the panelist's preference. The parameters were organoleptically determined using 15 trained panelists in the scoring test format. The data was analyzed using ANOVA and DNMRT at $95 \%$ confidence level. The results showed that the sugar concentration had a significant effect on the level of sweetness, the distinctive aroma of coffee, and instant coffee granules performance but had no significant effect on solubility and panelist preferences. The optimal sugar concentration to produce instant coffee with good quality was $25 \%$.
\end{abstract}

Keywords - libtukom, instant coffee, recrystallization, sugar added level

\section{INTRODUCTION}

Primary processed coffee products include ground coffee whereas one of the processed products derived is instant coffee. The process of making instant coffee with the cocrystallization method begins with the process of extracting ground coffee using hot water followed by the addition of sugar (a crystallizing agent) as well as heating to dry the extract and recrystallizing the sugar to produce a stable dry crystal. The addition of sugar and heating is the key to the process of instant coffee production by the co-crystallization method. The formation of crystals and the typical flavor of instant coffee are largely determined by the concentration of added sugar and the heat treatment that is applied during crystallization.

Instant drinks are categorized as processed food products in the form of powder [1], are easily soluble in water [2], are practical in serving, and having long shelf life [3, 4]. Instant coffee is made from coffee grounds extract using an extractor at a certain pressure. Extraction aims to separate the coffee extract from their pulp let after it becomes instant coffee it does not leave any sediment when brewed with water.

To convert coffee extracts into instant coffee, it is necessary to add sugar as a crystallizing agent [5]. Heating is needed to thicken the solution until it reaches its saturation point $(65 \%)$ after which the heat must be reduced to less than $90 \mathrm{oC}$ to prevent caramelization of sugar [6]. Intensive stirring is needed when sugar crystals begin to form in the extract solution. After all the sugar in the extract is crystallized, heat and stirring are still needed to dry the crystals until instant coffee is actually obtained under separate and dry granules [7, 8]. The recrystallization of sugar in the extract traps the mass of the coffee around the sugar, therefore the final sugar crystal has the taste and aroma of coffee and we can call it instant coffee.

The addition of sugar based on its function, is one of the factors that can affect the speed of crystal formation as well as sweeteners and preservatives. The method of crystallization in this way is called co-crystallization $[9,10]$. In this technique sucrose or granulated sugar acts as a coating which will cover the mass of coffee that is around it. The specialty of using sucrose as a coating due to the relatively cheap price, easily obtained, easily soluble in water, stable to heat, not too hygroscopic, and has a long shelf life at room temperature [11, $12]$.

The crystallization of sucrose in coffee extract begins when the concentration of sucrose is at a supersaturated level. The first nucleation stage in crystallization is called the primary nucleation stage. In the next step, if the solution continues to be cooled, the crystal cores formed in the previous stage will stick together, grow into larger size and settle to the bottom of the container. This crystallization stage is well-known as secondary nucleation stage $[13,14]$. When secondary nucleation occurs, primary nucleation will take place more intensely and the overall process of crystal formation will take place very quickly. During the secondary nucleation stage, heat is still needed to dry the crystals but it prefered not too hot because it can re-dissolve the crystals. Too high temperature leads to caramelize the sugar crystals. 
The purposes of this study were to determine the effect of sugar concentration on organoleptic quality of Liberika Tungkal Jambi instant coffee and to determine the optimal amount of sugar addition to produce the best organoleptic quality of instant coffee.

\section{MATERIAL AND METHODS}

\section{A. Material and Equipment}

The main material used was coffee grounds, granulated sugar, and mineral water. Liberika Tungkal Jambi coffee powder (libtujam) was obtained from Parit Tomo Village, Betara District, Tanjung Jabung Barat Regency, Jambi Province. Refined sugar and mineral water was obtained from a supermarket in the city of Jambi. The main equipment used was the scale, coffee extractor, thermometer, gas stove, frying pan, stirrer, blender, refractometer, and glassware for analysis.

\section{B. Methods}

Instant coffee was made by the method of cocrystallization. The crystallizing agent used was sugar at a concentration of $25 \%$. Coffee extract was made using an extractor in a ratio of hot water/coffee powder of $15 / 1$. Five levels of sugar concentration $(15,25,35,45$, and $55 \%)$ were applied in a completely randomized design with 4 replications. The parameters observed were the organoleptic qualities of instant coffee, including sweetness, distinctive aroma of coffee, granule texture, and panelist preferences. The parameters were organoleptically determined using 15 trained panelists in the scoring test format.

Coffee extract was made using the method of Mursalin et al. (2018); 300 gr coffee powder was placed in a coffee extractor and then added with $3000 \mathrm{ml}$ of $95^{\circ} \mathrm{C}$ hot water, stirred for 2 minutes, allowed to stand for 1 minute, then filtered to separate the pulp with the first extract. Furthermore, the pulp were added hot water again as much as $1500 \mathrm{ml}$, stirred for 1 minute, allowed to stand for 1 minute, then extracted again until the second extract was obtained. The first and second extracts were mixed and ready to be used as raw material for making instant coffee [15].

The cooking process in making instant coffee was performed using the method of Mursalin et al. (2018); it was divided into 5 stages, namely (1) preheating to reach the evaporation water temperature $\left(100-120^{\circ} \mathrm{C}\right)$ and removing some of the water from the coffee extract; (2) adding sugar to the coffee extract solution and thickening the mixture until the sugar concentration was reached at the saturation point $(65 \%)$; (3) prevent sugar caramelization by rapidly reducing the cooking temperature at $90^{\circ} \mathrm{C}$; (4) propagating the crystal core formation by slowly lowering the cooking temperature to $75^{\circ} \mathrm{C}$; and (5) allows the growth of the crystal core and at the same time dried the crystal to produce dispersed granules by keeping the cooking temperature at $75^{\circ} \mathrm{C}[15]$.

\section{RESUlT AND DisCUSSION}

Instant coffee production of by using co-crystallization method requires sugar (sukrosa). sugar in this method has a function as a crystallizing agent that can trap the coffee grains around the sugar. Since sugar has a sweet taste and hygroscopic properties, the instant coffee produced will also taste sweet and hygroscopic as well. Therefore the organoleptic quality of instant coffee is largely determined by the amount of sugar added.

\section{A. Organoleptic Quality of Instant Coffee}

Analysis of variance at 95\% confidence level and DNMRT at $5 \%$ significance level showed that sugar concentration significantly affected the texture of granules, the distinctive aroma of coffee, and the level of sweetness, but not for panelists' preferences. The effect of sugar concentration on several organoleptic quality parameters of Liberika-TungkalJambi instant coffee can be seen in Table 1.

TABLE 1

EFFECT OF SUGAR CONCENTRATION ON ORGANOLEPTIC QUALITY OF LIBERIKA-TUNGKAL-JAMBI INSTANT COFFEE

\begin{tabular}{lllll}
\hline $\begin{array}{l}\text { Sugar } \\
\text { Concentration } \\
(\%)\end{array}$ & $\begin{array}{l}\text { Panelists' } \\
\text { preferences }\end{array}$ & $\begin{array}{l}\text { Texture of } \\
\text { granules }\end{array}$ & Aroma & $\begin{array}{l}\text { Sweetness } \\
\text { level }\end{array}$ \\
\hline 15 & 3.20 & $3.90 \mathrm{a}$ & $4.35 \mathrm{a}$ & $2.35 \mathrm{a}$ \\
25 & 3.80 & $4.25 \mathrm{~b}$ & $3.40 \mathrm{~b}$ & $3.55 \mathrm{~b}$ \\
35 & 3.70 & $4.50 \mathrm{bc}$ & $3.25 \mathrm{~b}$ & $3.75 \mathrm{~b}$ \\
45 & 3.40 & $4.65 \mathrm{c}$ & $3.05 \mathrm{bc}$ & $3.75 \mathrm{~b}$ \\
55 & 3.36 & $4.75 \mathrm{c}$ & $2.65 \mathrm{c}$ & $3.85 \mathrm{~b}$ \\
\hline
\end{tabular}

Note: Numbers followed by different lowercase letters in the same column have a significant effect on the $5 \%$ significance level according to the DNMRT test.

\begin{tabular}{lllll}
\hline Score & $\begin{array}{l}\text { Panelists' } \\
\text { preferences }\end{array}$ & $\begin{array}{l}\text { Texture of } \\
\text { granules }\end{array}$ & Aroma & $\begin{array}{l}\text { Sweetness } \\
\text { level }\end{array}$ \\
\hline 5 & Very like & Very dry & Very strong & Very sweet \\
4 & like & Dry & Strong & Sweet \\
3 & Rather like & Sligtly moist & Medium & Medium \\
2 & Unlike & Moist & Less & Less sweet \\
1 & Very unlike & Very moist & Very less & Unsweet \\
\hline
\end{tabular}

It was found that there were 3 groups of texture conditions of instant coffee granules resulting from the treatment of sugar concentration. The first group with a slightly moist to dry texture, the second group with a dry texture, and the third group with a very dry texture. Table 1 showed that the higher the sugar concentration, the drier the instant coffee granules produced. The $25 \%$ sugar concentration produced granules with conditions that were not different from those produced by the $35 \%$ sugar concentration and better than those produced by $15 \%$.

The effect of sugar concentration on the distinctive aroma of coffee was different from the effect of it on the texture of the granules. The strength of the distinctive aroma of coffee was inversely proportional to the concentration of added sugar. It was found that the higher the concentration of sugar, the less the distinctive aroma of coffee that can be detected by panelists. The $25 \%$ sugar concentration produced granules with aroma that was no different from that produced by the sugar concentrations of 35 and $45 \%$ and better than those produced by $55 \%$.

The sweetness of instant coffee was influenced by the concentration of added sugar. But there was no tendency that increasing the concentration of sugar increase the sweetness of 
instant coffee. A $15 \%$ sugar concentration resulted in a lower level of sweetness, in contrast to the entire sugar concentration above it. However, sugar concentrations of $25,35,45$, and $55 \%$ produced instant coffee with a level of sweetness that was not different from each other. This showed that the sugar in the process of making instant coffee acted more as a crystallizing agent than as a sweetener.

Analysis of variance showed that sugar concentration had no significant effect on panelists' preference for instant coffee products. Panelist preferences were positively correlated with product taste while product taste was strongly influenced by flavor. This showed that the unique aroma of coffee in the product was not the only factor that determineed whether the product was being accepted or not. According to Winarno (2002), good flavor and taste stimulate the sense when taste the product and the impression when product had been swallowed [16].

\section{B. Addition of Optimal Sugar Concentration}

The analysis showed that the $25 \%$ sugar concentration was the optimal concentration for producing instant coffee by using co-crystallization methods. The sugar concentration of $25 \%$ produces instant coffee with a granular texture score between 4.25-4.50 (dry-very dry), the typical aroma of coffee between 3.05-3.40 (medium-strong); sweetness level between 3.55-3.85 (moderate-sweet); and the panelists' preference between 3.36-3.80 (rather like-like).

The concentration of sugar used in making instant coffee with the co-crystallization method was not the same for each type of coffee and sugar used. In making instant coffee from a Robusta and Arabica coffee mixture in a ratio of 1: 2, the amount of sugar (a mixture of coconut sugar and granulated sugar at a ratio of 30:70) added was $60 \%$ [17].

In fact, coffee syrup with the best organoleptic properties could only be produced with the addition of sugar of not less than $20 \%$ [18]. The presence of sugar in coffee will increase panelist acceptance. The highest level of consumer preference for robusta ground coffee brewing was obtained from the addition of $25 \mathrm{~g}$ of sugar for the use of $12 \mathrm{~g}$ of coffee powder and $180 \mathrm{ml}$ of hot water [19]. In making instant drinks of soursop leaf pollen, adding $28 \%$ sugar was the best treatment to produce instant drinks with the color, aroma, taste, and texture that panelists like most [10].

\section{CONCLUSION}

On the organoleptic quality of instant coffee, the concentration of sugar had a significant effect on the level of sweetness, distinctive aroma of coffee, and the state of coffee granules but not for panelists' preference.

The optimal sugar concentration to produce instant coffee Liberika Tungkal Jambi with good quality was $25 \%$ with the texture of granules dry to very dry, the typical aroma of coffee was moderate to strong, the level of sweetness was moderate to sweet, and the panelists' preferences were rather like to like.

\section{ACKNOWLEDGMENT}

We would like to thank the Chairperson of Jambi University LPPM for research funding and also to all those who support the works.

\section{REFERENCES}

[1] Rifkowaty E.E. dan Martanto. 2016. Minuman Fungsional Serbuk Instan Jahe (Zingiber officinalerosc) dengan Variasi Penambahan Ekstrak Bawang Mekah (Eleutherine americana Merr) Sebagai Pewarna Alami. Jurnal Teknik Pertanian Lampung Vol. 4, No. 4:315324.

[2] Nusa M.I., M. Fuadi, S. Fatimah. 2014. Studi Pengolahan Biji Buah Nangka Dalam Pembuatan Minuman Instan. Agrium Volume 19 (1). Hal 31-38.

[3] Kumalaningsih, S., Suprayogi dan B. Yudha. 2005. Membuat Makanan Siap Saji. Surabaya. Trubus Agrisarana. 41 hal.

[4] Yuliawaty. S.T., dan Susanto, W. H.. 2015. Pengaruh Lama Pengeringan dan Konsentrasi Maltodekstrin Terhadap Karakterisktik Fisik Kimia dan Organoleptik Minuman Instan daun Mengkudu (Morinda citrifolia L). Jurnal Pangan dan Agroindustri 3(1): 41-52.

[5] Sitompul N. 2014. Pengaruh Perbandingan Sari Mengkudu Dengan Sari Nanas Dan Jmlah Sukrosa Terhadap Mutu Minuman Serbuk Mengkudu Instan. Ilmu dan Teknologi Pangan. Jurnal Rekayasa Pangan Dan Pertanian.,Vol.2 No.1.

[6] Latief AS, R Syarief, B Pramudya, Muhadiono. 2010. Peningkatan Mutu Gula Tumbu Melalui Metode Sulfitasi Dalam Laboratorium. Jurnal Gema Teknologi Vol 16, No 1 Periode April 2010-Oktober 2010. Institut Pertanian Bogor.

[7] Nilasari OW, WH Susanto, JM Maligan. 2017. Pengaruh Suhu dan Lama Pemasakan Terhadap Karakteristik Lempok Labu Kuning (Waluh). Jurnal Pangan dan Agroindustri Vol.5 No.3:15-26.

[8] Fitriani S, A Ali, Widiastuti. 2013. Pengaruh suhu dan lama pengeringan terhadap mutu manisan kering jahe (Zingiber Officinale Rosc.) Dan Kandungan Antioksidannya. Jurnal Sagu, Vol. 12 No. 2 : 1-8.

[9] Chen AC, MF Veiga, dan AB Rizzuto. 1988. Cocrystallization: an encapsulation process. Di dalam: Deladino L, Navaro AS, dan Martino MN.Microstructure of minerals and yerba mate extract co-crystallized with sucrose. Journal of Food Engineering 96: 410-415.

[10] Ramadina, A. 2013. Pengaruh Penggunaan Jumlah Gula Terhadap Karakteristik. Inderawi Minuman Instan Serbuk Sari Daun Sirsak (Annona Muricata L). [Skripsi]. Fakultas Teknik Universitas Negeri Semarang. 105 halaman.

[11] Chen, AE., Viega, MF and Rizutto, AB. 1991. Cocrystalisasi, An Encapsulation Process, Food tech, 24, 1991 : 289-297.

[12] Agus MI. 2012. Pengaruh Suhu dan Lama Waktu Ekstraksi Terhadap Sifat Kimia dan Fisik Pada Pembuatan Minuman Sari Jahe Merah dengan Kombinasi Penambahan Madu Sebagai Pemanis. Jurnal Pangan dan Agroindustri 3(2): 530-541

[13] Earle, R. L., 2000. Unit Operation In Food Processing, Pergamen Press, New York.

[14] Setiyoningrum, P. 2011. Pembuatan Coro Instan Minuman Khas Pati Jawa Tengah (Skripsi). Bogor: Institut Pertanian Bogor.

[15] Mursalin, A Nizori, I Rahmayani. 2018. Teknologi Produksi Kopi Instan Liberika Tungkal Jambi dengan Metode Kristalisasi. Laporan Penelitian, Fateta Unja, Jambi. (Tidak dipublikasikan)

[16] Winarno, F. G. 2002. Kimia Pangan dan Gizi. PT. Gramedia Pustaka Utama: Jakarta.

[17] Praptiningsih YS, Tamtarini, Ismawati, dan S. Wijayanti. 2012. SifatSifat Kopi Instan Gula Kelapa Dari Berbagai Rasio Kopi RobustaArabika dan Gula Kelapa-Gula Pasir. Agrotek. 6(1): 70-77

[18] Mardhatilah D. 2015. Pengaruh Penambahan Konsentrasi Jahe dan Rempah pada Pembuatan Sirup Kopi. Agroteknose VI(2): 55-60

[19] Humaida S dan RP Astuti. 2018. Tingkat Kesukaan Konsumen Terhadap Penambahan Gula Semut Aren Pada Bubuk Kopi Robusta (Coffea canephora). Agropross National Conference Proceedings of Agriculture. Jurusan Produksi Pertanian, Politeknik Negeri Jember. Hal: 24-30. 